\title{
Sikap Kepribadian Guru PAUD yang Menarik dan Disukai Peserta Didik
}

\author{
Famahato Lase $^{1 凶}$, Adrianus Zega ${ }^{2}$ \\ Bimbingan dan Konseling. Institut Keguruan dan Ilmu Pendidikan Gunungsitoli, \\ Indonesia(1); Pendidikan Teknik Bangunan, Institut Keguruan dan Ilmu Pendidikan \\ Gunungsitoli, Indonesia( ${ }^{(2)}$ \\ DOI: 10.31004/obsesi.v6i3.1960
}

\begin{abstract}
Abstrak
Penelitian ini bertujuan untuk mengungkap, mengkaji lebih dalam apa adanya, secara spesifik dan urut mengenai kualitas sikap kepribadian guru dalam mendidik peserta didik. menggunakan metode deskriptif bersifat kuantitatif-kualitatif. Pengumpulan data dengan teknik skala likert menggunakan kuesioner, dan instrumen berupa angket tertutup yang dikembangkan berdasarkan pokok-pokok penelitian. Instrumen ini disebar secara acak dari populasi guru-guru PAUD di kota Gunungsitoli sebagai responden dan sumber data penelitian. Data dianalisis secara kuantitatif, dan selanjutnya hasilnya akan dideskripsikan secara kualitatif. Hasil penelitian mengungkap bahwa kualitas sikap kepribadian guru berada pada kategori kurang dan sikap kepribadin ini berdampak besar terhadap motivasi belajar peserta didik, baik secara positif maupun negatif. Direkomendasikan kepada para pendidik agar mengembangkan kualitas sikap kepribadian yang baik.
\end{abstract}

Kata Kunci: anak usia dini; guru yang disukai ; sikap kepribadian

\begin{abstract}
This study aims to uncover, examine more deeply what it is, and describe specifically and sequentially about the quality of the teacher's personality in educating students, using a quantitative-qualitative descriptive method. Collecting data using a likert scale technique using a questionnaire, and the instrument is a closed questionnaire which was developed based on the main points of the research. This instrument was distributed a random sample to the population of PAUD teachers in the city of Gunungsitoli as well as respondents and sources of research data. The data are analyzed quantitatively, and then the results will be described qualitatively. The results of the study revealed that the quality of the teacher's personality attitude was in the poor category and this personality attitude had a major impact on students' learning motivation, both positively and negatively. So it is recommended to educators to develop a good quality personality attitude.
\end{abstract}

Keywords: personality attitude; preferred teacher; early childhood

Copyright (c) 2021 Moh. Anwar

$\triangle$ Corresponding author :

Email Address : famstemos@gmail.com (Gunungsitoli, Indonesia)

Received 17 July 2021, Accepted 23 December 2021, Published 26 Desember 2021

famstemos@gmail.com

Jurnal Obsesi : Jurnal Pendidikan Anak Usia Dini, 6(3), 2022 | 2107 


\section{PENDAHULUAN}

Keberhasilan seorang pendidik dalam menyelenggarakan pembelajaran pada siswa Pendidikan Anak Usia Dini atau PAUD (Fitriana, 2019) tidak selalu ditentukan oleh kecakapan mengajar (Supriyanto et al., 2019) dan penguasaannya materi yang diajarkan (Aryani, 2020). Salah satu hal yang amat penting dan sangat besar pengaruhnya terhadap keberhasilan kegiatan belajar peserta didik (Göncz, 2017; Lukman et al., 2021) adalah kepribadian menarik (Lase, 2016) dan disukai peserta didik (Dost et al., 2017). Sebaliknya sikap yang jelek juga akan berdampak negatif, yakni membuat peserta didik tidak termotivasi untuk belajar, tidak menyukai pembelajaran (Santoso et al., 2017), dan tidak senang bahkan membenci gurunya (Boström, 2020). Jika kegiatan belajar peserta didik lemah karena tidak termotivasi, maka sehebat-hebatnya guru mengajar di kelas, hasil belajar yang optimal tidak akan tercapai. Begitu juga sebaliknya selemah-lemahnya guru mengajar di kelas, apabila peserta didik belajar sehebat-hebatnya karena memiliki motivasi yang tinggi yang ditimbulkan oleh kepribadian guru yang menarik dan disukai peserta didik (Noreen et al., 2019), maka hasil belajar yang tinggi (Ananda, 2017) bahkan setinggi-tingginya mudah tercapai (Prayitno, 2019). Oleh karena itu setiap pendidik perlu mengembangkan kepribadian yang baik dalam dirinya (Norsidah et al., 2017).

Hasil penelitian sebelumnya menyimpulkan bahwa: 1) terdapat korelasi yang kuat antara kepribadian guru dengan motivasi belajar siswa (Huda, 2017);2) faktor psikologis yaitu motivasi guru berpengaruh signifikan terhadap kinerjanya (Pratiwi et al., 2021); 3) kepribadian guru berpengaruh signifikan terhadap karakter siswa (Astuti et al., 2021); dan 4) faktor dukungan sosial berpengaruh positif terhadap kinerja guru (Novitasari et al., 2021). Sedangkan penelitian ini bertujuan untuk mengungkap dan mengembangkan bagaimana sikap kepribadian guru PAUD yang menarik dan disukai oleh peserta didik. Sikap ini menyangkut 9 aspek yang terukur, yakni kepribadian yang suka: 1) memberi pujian yang tulus dan jujur kepada peserta didik, 2) membangkitkan semangat, 3) mendengar, 4) senyum, 5) menghindari kebiasaan men-SOK (salahkan, omelin, kritik), 6) memberi perhatian, 7) mementingkan orang lain, 8) menyebut nama, dan 9) membicarakan hal-hal yang diminati dan disukai peserta didik, seperti kajian berikut ini.

Kepribadian pendidik yang suka memberi pujian, amat diperlukan. Salah satu kebutuhan dasar peserta didik sebagai individu adalah pujian (McDevitt, 2021; Le, 2021), mereka haus akan pujian, penghargaan yang tulus, dan jujur dari pendidik. Keinginan ini merupakan sifat-sifat dasar manusia yang membedakannya dengan hewan (Van, 2021; Bøsterud, 2021). Sangatlah penting untuk memenuhi kebutuhan ini dalam pembelajaran yang diselenggarakan guru, sebab ini salah satu upaya untuk menciptakan motivasi belajar yang tinggi dan semangat besar dalam diri peserta didik. Apabila kondisi ini tercipta, maka mereka menyenangi guru dan kegiatan pembelajaran (Yu, 2021). Namun jika meremehkan, tidak menghargai, dan pelit untuk memberi pujian dan penghargaan, akan melemahkan semangat dan motivasi belajar mereka (Sandi et al., 2021; Lohbeck, 2021).

Sebagai contoh hasil percobaan yang telah dilakukan oleh seorang guru kepada beberapa orang peserta didik yang memiliki kemampuan belajar lemah atau IQ kurang tinggi tetapi selalu diberi pujian dan penghargaan, menyimpulkan bahwa hasil belajarnya lebih baik dari pada mereka yang memiliki kemampuan belajar/ IQ tinggi tetapi selalu diremehkan, diomelin, dipersalahkan, dan dikritik terus-menerus (Sternberg et al., 2007). Telah membuktikan bahwa pujian dan penghargaan dari seorang pendidik sangat meningkatkan prestasi belajar dan begitu sebaliknya (Basalamah, 2021; Kumar, 2019). Penghargaan, berprestasi, berkompetisi, mendapat dukungan dan pengakuan merupakan kebutuhan dasar dari setiap individu (Mulang, 2021). Apabila kebutuhan ini dapat terpenuhi dalam diri peserta didik oleh pendidik dalam kegiatan pembelajaran, maka mereka akan semakin termotivasi untuk melakukan kegiatan belajar yang tinggi dan mencapai hasil optimal (Rafiola et al., 2020). Oleh karena itu dalam memberikan pujian dan penghargaan, pendidik perlu 
menunjukan sikap penuh pengertian, penerimaan, hubungan yang akrab, sabar, ramah penuh kasih sayang dan kehangatan, toleransi, empati yang tinggi, adil, dan memberi kebebasan kepada peserta didik (Khaidir et al., 2021).

Perlu diperhatikan oleh para pendidik setiap kali menyelenggarakan kegiatan pembelajaran, apakah meningkatkan atau menghancurkan prestasi belajar peserta didik (Portana et al., 2021), apakah yang ditampilkan adalah kepribadian yang menarik dan disukai yakni memberi pujian dan penghargaan, atau kepribadian yang jelek yakni meremehkan, tidak menghargai, dan pelit memberi pujiuan. Namun pendidik yang berhati mulia, tulus dan jujur, pasti menghargai peserta didiknya, memuji dan menghormatinya (Hanna et al., 2020). Pendidik yang berkepribadian seperti ini semakin disukai peserta didik, banyak teman dan sahabat, dan kemana saja dia pergi, selalu disukai karena senantiasa memberi hal yang positif kepada orang lain (Purbalingga et al., 2021).

Kepribadian pendidik yang suka membangkitkan semangat, berdampak besar terhadap pembelajaran. Membangkitkan semangat peserta didik untuk berhasil dalam belajar (Setiawan, 2017) bagaikan menyalakan generator pembangkit tenaga listrik yang memiliki power/dinamika besar, dan mudah dialirkan tenaganya menjadi energi, cahaya, dan panas, dibandingkan jika tidak menyala. Demikian juga halnya dengan seorang pendidik yang berlaku sebagai pembakar semangat pada peserta didiknya. Apabila semangat mereka sudah menyala untuk belajar (Troy et al., 2020), tinggal memacu mereka melakukan kegiatan pembelajaran yang tinggi (Kaso et al., 2021).

Setiap pendidik perlu menjadi pembakar semangat dan motivator sejati pada peserta didiknya dalam kegiatan pembelajaran (Kahar, 2018). Pribadi yang optimis lebih disukai (Genç, 2021) dari pada si pesimistis dan pematah semangat yang membosankan (Werdani, 2021). Si pembakar semangat, selalu berpikir positif, optimis, ulet, pantang menyerah (Robinson, 2017), tetap tenang menghadapi masalah, berpikir dan berkata positif, banyak ide dan gagasan (Simkhada et al., 2021), tidak pernah meremehkan dan mengabaikan kemampuan dan impian orang lain serta selalu menguatkan semangat peserta didiknya untuk berhasil (Baharun, 2018).

Sebagai seorang pendidik, perlu mendorong kemampuan berpikir kreatif dan menghindari sifat-sifat yang suka mematahkan semangat peserta didik, sifat pesimistik, dan sikap membentak-bentak dan meremehkan, dan lain sejenisnya (Rahman, 2017). Sifat negatif ini menjadi wabah yang akan menghancurkan semangat belajar (Anwar et al., 2020). Tetapi upaya memicu dan memacu peserta didik untuk belajar dengan motivasi yang tinggi dan semangat yang besar sangat penting dalam kegiatan pembelajaran (Moh Ghoizi et al., 2021). Kecakapan membangkitkan semangat peserta didik adalah salah satu keterampilan yang perlu dimilkiki oleh setiap pendidik. Menciptakan kondisi belajar pada peserta didik sangat berbeda dengan mengajarkan materi pembelajaran. Jika kondisi belajar sudah tercipta (Tyas, 2021), maka penyelenggaraan kegiatan pembelajaran menjadi mudah, karena semangat merupakan power belajar yang menyala bagi peserta didik (Altun, 2017).

Menyelenggarakan pembelajaran, menciptakan kondisi belajar, dan membangkitkan motivasi yang tinggi dan semangat yang besar dalam diri peserta didik, merupakan prinsip yang amat penting (Boström, 2020; Dang et al., 2021). Kegiatan pembelajaran menjadi mudah dilakukan apabila dalam diri peserta didik sudah tercipta kondisi belajar yang berkualitas tinggi (Sogunro, 2014). Mereka akan melakukan kegiatan belajar sehebat-hebatnya, dan akan mencapai hasil yang optimal (Wahono et al., 2020). Oleh sebab itu, pendidik perlu menjadi pembakar semangat dan motivator sejati bagi peserta didiknya (Brown, 2004). Pendidik yang memiliki kepribadian seperti ini pasti disukai oleh peserta didiknya dan pembelajaran yang diselenggarakannya (Perryman, 2020).

Kepribadian pendidik yang suka mendengar peserta didik, sangat diperlukan. Orang yang paling menjemukan dalam pergaulan dan dalam interaksi atau komunikasi adalah orang yang tidak mau mendengarkan dan yang lebih suka memotong pembicaraan orang lain 
ketika berbicara (Erlangga, 2017). Begitu juga dalam kegiatan pembelajaran, orang yang paling banyak berbicara adalah guru, dan sangat sedikit kesempatan untuk mendengarkan peserta didik (Hidayati, 2018). Padahal banyak yang perlu dibicarakan dan amat penting didengar dari peserta didik oleh guru (Syahrani et al., 2021), sebab berbicara dan didengar merupakan salah satu kebutuhan dasar manusia sebagai individu (Rosid, 2021). Mendengar dimaksud adalah menghargai setiap pendapat peserta didik, mendengar keluhan mereka dan meresponi dengan penuh empati (Wulandani, 2021). Sehingga pembelajaran yang diselenggarakan pendidik lebih tepat dan sangat cocok sesuai dengan keadaan peserta didik.

Pemberian kesempatan kepada peserta didik untuk berbicara dan didengar (Mudiyah 2021; Sakliressy et al., 2021), berarti memberi hal yang positif kepada peserta didik, (Warsah, 2019) yaitu membuat mereka lebih aktif dalam kegiatan pembelajaran (Amijaya et al., 2018; Khairani, 2018). Begitu juga secara tidak langsung, mendidik mereka untuk menghargai orang lain ketika berbicara (Rahmah, 2018; Ahsani, 2021). Sangat penting menghargai pendapat peserta didik dalam kegiatan pembelajaran (Apriliani, 2019), karena inilah yang membuat mereka semakin termotivasi untuk belajar (Septian, 2019). Oleh karena itu jika pendidik ingin memiliki kepribadian menarik dan disukai peserta didik, perlu mendengar dan menghargai pendapat mereka.

Kepribadian pendidik yang suka senyum, sangat diperlukan. Tanpa disadari, penampilan pendidik di depan kelas dengan wajah yang cenderung serius, murung, muram, garang (Ghofar, 2013), sulit dan pelit untuk senyum dalam kegiatan pembelajaran (Rahardi, 2011). Sikap ini menimbulkan pada peserta didik rasa takut, dan ingin menghindari pribadi seperti ini (Barseli, 2017; Oktawirawan, 2020). Tetapi pendidik yang memiliki wajah suka senyum penuh kemesraan dengan tidak dibuat-buat, tulus dan jujur (Ramawati et al., 2021), menimbulkan dampak positif yang sangat besar kekuatannya terhadap motivasi dan semangat belajar bagi peserta didik. Dari senyum seorang pendidik akan terlihat oleh peserta didik, apakah dia seorang yang ramah atau tidak. Pendidik yang ramah penuh kemesraan, penyayang, bersahabat, lemah lembut, menyenangkan, memiliki sifat humor, dan lain sejenisnya (Nasution, 2019), pasti disukai oleh peserta didiknya, serta kesemuanya ini sangat berpengaruh besar secara positif terhadap belajar mereka (Kamandoko, 2009). Senyum merupakan salah satu bahasa tubuh yang sangat besar kekuatannya, untuk membuat rasa senang pada orang lain maupun diri sendiri (Rumayar, 2011). Kekuatan ini akan membangkitkan power belajar, yakni semangat yang besar dan motivasi yang tinggi dalam diri peserta didik untuk melakukan kegiatan belajar (Fadilah et al., 2021). Jika peserta didik menyenangi gurunya, pasti pula menyenangi mata pelajaran yang diajarkannya, dan ini yang membuat mereka suka melakukan kerja keras dalam kegiatan pembelajaran.

Sifat ramah, senyum yang tulus dan jujur dari seorang pendidik (Azis, 2017), kelihatannya sepele, namun ini merupakan salah satu daya yang sangat besar (Pertemuan, 2021), dan mampu membangkitkan motivasi yang tinggi dan semangat yang besar dalam diri peserta didik untuk belajar (Sumiati, 2021). Hasil sebuah penelitian mengungkap bahwa sisipan humor waktu kegiatan pembelajaran meningkatkan prestasi belajar secara signifikan (Lesser et al., 2016; Melrose, 2021), dan merekomendasikan agar pendidik menyisipkan humor dalam kegiatan pembelajaran (Ziyaeemehr et al., 2011; Goodboy et al., 2014). Kegiatan pembelajaran merupakan proses interaksi antara pendidik dengan peserta didik, dan sesama, maka sifat ramah dan senyum merupakan hal yang sangat penting (Krys et al., 2016). Oleh karena itu, pendidik perlu tampil di depan peserta didiknya dengan wajah yang senyum senantiasa. Jika pendidik ingin menjadi pribadi yang menarik dan disukai, senyumlah senantiasa.

Kepribadian pendidik yang kebiasaan menyalahkan, mengomelin, dan mengkritik, perlu dihindari. Dapat ditegaskan bahwa semua peserta didik tidak suka di SOK (Salahkan, Omelin, Kritik) atau dibentak-bentak, direndahkan (Vega et al., 2019), sikap bullying, tidak dihargai, dan lain sejenisnya (Amoo et al., 2021). Sikap ini akan menjadi virus dan wabah yang 
akan membahayakan diri peserta didik dan pendidik itu sendiri dalam kegiatan pembelajaran (Xu \& Cooper, 2020). Sikap seperti ini merupakan pelecehan bahkan penganiayaan terhadap peserta didik, karena berdampak negatif terhadap motivasi dan semangat belajar (Gilmore et al., 2003).

Pendidik yang berhati mulia pasti menghindari kebiasaan ini, dan memperlakukan peserta didik dengan ramah, lembut, menyayangi, baik hati, bersahabat, berkata santun, menghargai, mengasuhnya dengan baik, dan lain sejenisnya (Gani, 2019). Sebagai seorang profesional, pendidik memiliki sifat-sifat lembut, menyenangkan, suka memberi dan tidak banyak menuntut (Stark, 2021), luwes, hangat, dapat menerima orang lain, mengenal dirinya sendiri, tidak berpura-pura, menghargai orang lain, tidak mau menang sendiri, dan obyektif (Munro, 1993). Selain itu, dia juga berupaya mengerti peserta didik, mengadakan penyesuaian, membina serta memelihara sikap ramah tamah dan sopan santun, mengusahakan agar setiap peserta didik merasa nyaman (Madukwe et al., 2019), memberi ketenangan, menciptakan suasana tentram, rasa percaya, dan selalu berada dalam kondisi yang baik, serta meninggalkan prasangka-prasangka negatif (Koerstoer, 1985). Menaruh perhatian, tanggung jawab sepenuhnya, mengasihi tanpa syarat, demi pemeliharaan hidup dan pertumbuhan, serta menanamkan ke dalam diri mereka kehidupan dan tidak hanya keinginan untuk tetap hidup (Mustopo, 1987). Sikap ini semua merupakan kepribadian seorang pendidik yang menarik dan disukai oleh peserta didik, yang kesemuanya berdampak positif terhadap kegiatan pembelajaran (Buttner et al., 2016). Untuk itu, jika pendidik ingin menjadi pribadi yang menarik dan disukai peserta didik, maka perlu menghindari sifat-sifat men-SOK peserta didik, serta mengembangkan terus sikap kepribadian yang baik.

Kepribadian pendidik yang suka memberi perhatian yang tulus, perlu dikembangkan. Salah satu kesulitan besar dalam kegiatan pembelajaran adalah kurangnya perhatian pendidik terhadap peserta didiknya (Novitasari et al., 2021). Ahli psikologi Alfred Adler menegaskan bahwa orang yang mengalami kesulitan terbesar dalam hidupnya dan yang paling menyulitkan orang lain adalah orang yang tidak mempunyai perhatian pada orang lain (Lilleheie et al., 2021). Begitu juga dalam kegiatan pembelajaran, kesulitan besar terjadi (Mohammad \& Hazarika, 2016) karena kurangnya kepedulian dan perhatian pendidik terhadap peserta didiknya (Darong et al., 2020). Sifat ini perlu diubah oleh pendidik dan mengembangkan dalam dirinya kepribadian yang suka memperhatikan orang lain dan peserta didiknya (Bas \& Tabancali, 2020). Pribadi yang pemerhati pasti disenangi oleh peserta didiknya dan kegiatan pembelajaran yang diselenggarakannya (Ginja, 2020). Juga perhatian yang tulus dan jujur (Suyatno et al., 2019), membawa dampak positif yang sangat besar terhadap motivasi belajar peserta didik (Idris et al., 2018). Untuk itu jika pendidik ingin menjadi pribadi yang menarik dan disukai, jadilah seorang pemerhati sejati bagi peserta didik.

Keperibadian pendidik yang suka mementingkan orang lain, perlu dimiliki. Pada kegiatan pembelajaran, biasanya yang merasa dan dianggap sebagai orang pengting atau veri importen person (VIP) adalah guru, tempatnya pasti di depan kelas (Yanti et al., 2020). Jarang pendidik menganggap peserta didiknya sebagai orang penting (Lumban Gaol, 2019). Padahal pada interaksi kegiatan pembelajaran (Luo et al., 2019; Tasgin, 2018), memerlukan hubungan yang harmonis antara pendidik dengan peserta didik dan membuat mereka sebagai orangorang penting (Sejati et al., 2019). Hal ini ditegaskan karena sebagai individu mereka membutuhkan dan sangat haus untuk diperlakukan sebagai orang orang penting (Kusumaningrum et al., 2019). Secara psikologi, pendidik yang mem-VIP-kan peserta didiknya seperti ini, telah menciptakan hal yang positif dalam diri mereka, yaitu dorongan yang kuat, motivasi yang tinggi, dan semangat yang besar untuk belajar (Cheng \& Dörnyei, 2007). Mempedulikan dan memperlakukan peserta didik menjadi VIP sebagai orang penting adalah mendidik mereka untuk menghargai dan mempedulikan orang lain (Tamara, 2016). Merupakan hal biasa dimana-mana dan lumrah terjadi jika peserta didik, dituntut untuk menghormati, menganggap dan memperlakukan gurunya sebagai orang penting (Ashsiddiqi, 
2012; Djuwita, 2017), dan justru gurulah yang merasa haus dan marah-marah jika peserta didiknya silaf memperlakukannya sebagai orang penting (Muis, 2017). Tetapi tidak biasa jika guru menjadi teladan yang memperlakukan mereka sebagai orang penting (Sari, 2017). Inilah salah satu upaya pendidik untuk menciptakan motivasi yang tinggi dan semangat yang luar biasa dalam diri peserta didik untuk melakukan kegiatan belajar (Oktiani, 2017). Lemahnya semangat belajar, sering kali diakibatkan oleh sifat ini (Murti, 2020). Melalui pemenuhan rasa haus peserta didik menjadi orang penting oleh pendidik, motivasi dan semangat belajar dapat tercipta untuk mencapai hasil yang optimal. Oleh karena itu jika pendidik ingin menjadi pribadi yang menarik dan disukai peserta didik, buatlah mereka menjadi VIP/orang penting dalam kegiatan pembelajaran.

Kepribadian pendidik yang suka menyebut nama peserta didik dengan benar, perlu dilakukan. Menyebut nama peserta didik dengan benar dan tepat saat kegiatan pembelajaran (Rasam 2018) sangatlah penting, walaupun kelihatannya sepele, namun membawa dampak positif yang sangat besar pengaruhnya dalam diri individu peserta didik, untuk lebih giat belajar (Cahyani et al., 2020). Hal ini ditegaskan karena ketika nama seseorang disebut, rasa bangkit untuk lebih giat belajar, muncul dalam diri mereka. Bagaikan orang yang dibangunkan dari tidurnya (Musofa et al., 2019), begitulah seseorang ketika disebut namanya dalam komunikasi, pendengarannya langsung meresponinya. Ini bisa terjadi, karena nama adalah bunyi yang paling harum dan merdu bagi pemiliknya. Menyebut nama berarti membangkitkan semangat untuk lebih giat belajar. Ini sangat berpengaruh dan memberi kontribusi besar secara positif, bagi orang yang disebut namanya, membuatnya merasa diperlakukan secara istimewa (Rumbewas et al., 2018).

Kegiatan pembelajaran, membuthkan komunikasi dan interaksi yang efektif (Triwardhani et al., 2020). Salah satu upaya yang perlu dilakukan adalah menyebut nama peserta didik dengan benar dan tepat, karena sangat mempercepat keakraban. Dengan ini juga sangat pantang pada pendidik, menyebut atau memberi lebel yang negatif kepada peserta didik, karena akan membawa pengaruh negatif terhadap mereka. Berdasarkan hasil percobaan yang dilakukan penulis di depan para siswa di salah satu sekolah, dan mencoba menyebut nama-nama peserta didik dengan banar dan tepat (Sari, 2016). Juga memberi lebel positif kepada mereka dengan berkata: saya menjadi segan berdiri di depan kelas ini, karena sedang berhadapa dengan orang-orang hebat, yakni generasi penerus, calon-calon pemimpin bangsa masa depan, calon-calon pejabat, dan di tangan orang-orang seperti ini terletak masa depan bangsa. Hasil percobaan ini menunjukan hal yang sangat positif, yakni membuat mereka semakin antusias dan sungguh-sungguh mengikuti pembelajaran (Sihaloho et al., 2020), karena semuanya merasa diperlakukan secara istimewa. Apabila sudah tercipta keakraban pendidik dengan peserta didik, maka kegiatan pembelajaran akan lebih mudah dan menyenangkan (Mahmudah, 2018). Dengan demikian, pendidik yang berkepribadian menarik dan disukai peserta didik adalah yang suka menyebut nama peserta didiknya dengan benar, tepat, dan tidak memberi lebel negatif.

Kepribadian pendidik yang suka membicarakan hal-hal menarik, perlu dilakukan. Salah satu keberhasilan pendidik dalam pembelajaran adalah kepeduliannya terhadap peserta didiknya (Komarudin, 2021), dan ini sangat dibutuhkan oleh mereka. Kepedulian dimaksud adalah upaya untuk menemukan dan membicarakan hal-hal menarik, yang disukai oleh peserta didik menyangkut hal belajar (Amaruddin et al., 2020). Hal-hal menarik yang diminati tersebut, misalnya kesuksesan, masalah belajar, cita-cita, karir dan masa depan, dan berbagai hal menarik lainnya (Laksana, 2019). Membicarakan hal-hal menarik ini, membantu mereka memecahkan masalah yang dialami (Muna, 2020), membahas hal-hal yang berkaitan dengan hidup sehari-hari dan masa yang akan datang terkait pembelajaran (Muhyatun, 2019).

Salah satu penyebab utama kesulitan belajar siswa, dan kurangnya perhatian dan tanggapan mereka terhadap apa yang dibicarakan guru, adalah terlalu banyak hal yang tidak menarik dan tak diminati peserta didik. Misalnya membicarakan hal-hal yang sulit dimengerti 
dan kurang cocok dengan kemampuan mereka untuk memahaminya, tanpa menyesuaikannya dengan hal-hal yang diminati (Farista, 2018). Akibatnya, mulai timbul dalam diri peserta didik, rasa kurang menyenangi guru dan pembelajaran yang diselenggarakannya (Kusuma, 2019). Untuk itu, setiap pendidik perlu berupaya menemukan dan membicarakan hal-hal yang menyenangkan dan diminati peserta didiknya (Wulandani, 2021). Dengan demikian, setiap kali kegiatan pembelajaran direncanakan, dan dilaksanakan, perlu mengaitkannya dengan hal-hal yang menyenangkan dan diminati mereka (Fitria, 2019). Oleh karena itu, menjadi pendidik yang menarik dan disukai peserta didik, adalah menjadi pendidik yang suka membicarakan hal-hal yang menyenangkan dan diminati mereka.

\section{METODOLOGI}

Penelitian ini menggunakan metode deskriptif bersifat kuantitatif-kualitatif, untuk mengungkap, mengkaji lebih dalam apa adanya, dan mendeskripsikan secara spesifik dan urut, suatu pristiwa, situasi, perilaku, subjek, atau fenomena tentang sikap kepribadian guru yang menarik dan disukai peserta didik, menyangkut bentuk-bentuk sikap yang suka: 1) memberi pujian kepada peserta didik, 2) membangkitkan semangat, 3) menghindari kebiasaan menyalahkan, mengomelin, dan mengkritik, 4) senyum, 5) mementingkan orang lain, 6) memberi perhatian, 7) mendengar, 8) menyebut nama dengan benar, dan 9) membicarakan hal-lal menarik yang disukai peserta didik.

Peneliti berusaha mengumpulkan informasi, untuk menjawab pertanyaan penelitian, tentang apa, kapan, siapa, dimana, dan bagaimana permasalahan yang diteliti, dengan memperhatikan aspek data-data penelitian yang diperoleh (Sugiyono, 2015; Abdullah, 2015; Rai Utama, 2017). Lokasi penelitian adalah kota Gunungsitoli, populasi penelitian adalah guru-guru PAUD se-kota Gunungsitoli, dan sampel diambil secara random. Teknik pengumpulan data adalah skala likert menggunakan kuesioner, dan instrumen pengumpul data, adalah angket tertutup sebanyak 60 butir dan lima alternatif pilihan jawaban (selalu, umumnya, sering, kadang-kadang, dan jarang), yang dikembangkan berdasarkan pokok-pokok penelitian, dan disebar kepada subjek 60 orang responden sumber data. Objek dan data penelitian yang dikumpul, adalah data-data tentang kepribadian guru PAUD yang menarik dan disukai peserta didik (1-9). Data dianalisis secara kuantitatif, dan selanjutnya hasilnya akan dideskripsikan secara kualitatif.

\section{HASIL DAN PEMBAHASAN}

Hasil penelitian mengenai sikap kepribadian guru PAUD yang menarik dan disukai dalam mendidik peserta didik dapat dilihat pada tabel 1.

Berdasarkan hasil analisis data penelitian di atas secara keseluruhan, diperoleh skor rata-rata sebesar 195,38 atau 65,13\% dari skor ideal 300. Skor ini berdasarkan kriteria penilaian sikap kepribadian, berada pada rentang, antara 180-240,99 dengan penilaian angka 3 artinya Kurang. Sikap kepribadian guru PAUD dalam mendidik peserta didik ini, menyangkut kepribadian yang suka: memberi pujian yang tulus dan jujur, membangkitkan semangat, mendengar, senyum, menghindari kebiasaan men-SOK, memberi perhatian, mementingkan, menyebut nama, membicarakan hal-hal yang diminati dan disukai peserta didik, seperti dibahas aspek-aspeknya berikut ini.

Pujian yang tulus dan jujur, merupakan kebutuhan dasar setiap individu peserta didik, yang perlu diberikan oleh pendidik dalam kegiatan pembelajaran. Pemenuhan kebutuhan ini, berdampak besar terhadap motivasi belajar mereka. Jika kebutuhan dasar ini terpenuhi, maka peserta didik, akan menyenangi gurunya, dan pembelajaran yang diselenggarakannya, serta akan melakukan kegiatan belajar yang hebat, dan mencapai hasil belajar yang optimal (Lohbeck, 2021; Mulang, 2021). Begitu juga sebaliknya, jika pendidik pelit memberi pujian, dan malah mengabaikan atau meremehkan peserta didik, akan membuat mereka tidak senang kepada pendidik, dan tidak menyukai pembelajaran yang diselenggarakannya. Berdasarkan 
hasil analisis data penelitian yang telah dilakukan, diperoleh skor hanya sebesar 29,38 atau $65,30 \%$ dari skor ideal 45 dengan penilaian angka 3 yang artinya sikap kepribadian pendidik dalam memberi pujian yang tulus dan jujur kepada peserta didik, berada pada kategori kurang. Skor ini belum mencapai skor ideal, artinya pendidik kurang suka memberi pujian yang tulus dan jujur kepada peserta didiknya dalam kegiatan pembelajaran. Dari hasil wawancara yang dilakukan, ada siswa yang menyampaikan kepada orang tuanya sambal menangis karena gurunya menyebut dia orang bodoh. Sikap ini sangat mematahkan semangat peserta didik dalam belajar dan membuat mereka menganggap dirinya sebagai orang yang lemah dan tidak mampu belajar dengan baik.

Tabel 1. Persentase Skor Sikap Kepribadian Guru terhadap Peserta Didik

\begin{tabular}{|c|c|c|c|c|c|c|c|}
\hline \multirow[t]{2}{*}{ No } & & \multirow[t]{2}{*}{ Aspek Sikap Kepribadian } & \multirow{2}{*}{$\begin{array}{c}\text { Skor } \\
\text { Idea } \\
1\end{array}$} & \multicolumn{2}{|c|}{$\begin{array}{c}\text { Skor \& } \\
\text { Persentase }\end{array}$} & \multirow{2}{*}{\multicolumn{2}{|c|}{$\begin{array}{c}\text { Kriteria } \\
\text { Penilaian } \\
\text { dengan Angka \& } \\
\text { Huruf } \\
\end{array}$}} \\
\hline & & & & $\mathrm{f}$ & $\%$ & & \\
\hline 1 & K1 & $\begin{array}{l}\text { Sikap kepribadian guru yang suka memberi } \\
\text { pujian dengan tulus dan jujur kepada peserta } \\
\text { didik }\end{array}$ & 45 & 29,38 & 65,30 & 3 & Kurang \\
\hline 2 & K2 & $\begin{array}{l}\text { Sikap kepribadian guru yang suka } \\
\text { membangkitkan semangat peserta didik } \\
\text { dalam belajar }\end{array}$ & 30 & 19,67 & 65,56 & 3 & Kurang \\
\hline 3 & K3 & $\begin{array}{l}\text { Sikap kepribadian guru yang suka } \\
\text { mendengar peserta didik }\end{array}$ & 30 & 19,25 & 64,17 & 3 & Kurang \\
\hline 4 & K4 & $\begin{array}{l}\text { Sikap kepribadian guru yang suka senyum } \\
\text { kepada peserta didik }\end{array}$ & 30 & 18,97 & 63,22 & 3 & Kurang \\
\hline 5 & K5 & $\begin{array}{l}\text { Sikap kepribadian guru yang suka } \\
\text { menghindari kebiasaan men-SOK (Salahkan, } \\
\text { Omelin, Kritik) peserta didik }\end{array}$ & 45 & 29,88 & 66,41 & 3 & Kurang \\
\hline 6 & K6 & $\begin{array}{l}\text { Sikap kepribadian guru yang suka memberi } \\
\text { perhatian yang tulus dan jujur kepada } \\
\text { peserta didik }\end{array}$ & 30 & 19,58 & 65,28 & 3 & Kurang \\
\hline 7 & K7 & $\begin{array}{l}\text { Sikap kepribadian guru yang suka } \\
\text { mementingkan peserta didik }\end{array}$ & 30 & 19,82 & 66,06 & 3 & Kurang \\
\hline 8 & K8 & $\begin{array}{l}\text { Sikap kepribadian guru yang suka menyebut } \\
\text { nama peserta didik dengan benar dan tepat }\end{array}$ & 30 & 19,52 & 65,06 & 3 & Kurang \\
\hline 9 & K9 & $\begin{array}{l}\text { Sikap kepribadian guru yang suka } \\
\text { membicarakan hal-hal yang disukai dan } \\
\text { diminati peserta didik. }\end{array}$ & 30 & 19,32 & 64,39 & 3 & Kurang \\
\hline Total & К1-K9 & $\begin{array}{l}\text { Sikap kepribadian guru secara keseluruhan } \\
\text { kepada peserta didik }\end{array}$ & 300 & 195,38 & 65,13 & 3 & Kurang \\
\hline
\end{tabular}

Kecakapan membangkitkan motivasi peserta didik untuk belajar, adalah salah satu keterampilan yang perlu dimilikiki oleh setiap pendidik. Kepribadian yang optimis, dan suka membangkitkan semangat peserta didiknya dalam belajar, lebih disukai dengan pembelajaran yang diselenggarakannya, dari pada si pesimistik dan pematah semangat yang membosankan. Pendidik yang memiliki sikap kepribadian seperti ini, selalu berpikir dan berkata positif, optimis, ulet, pantang menyerah, tetap tenang menghadapi masalah, banyak ide dan gagasan, tidak pernah meremehkan dan mengabaikan kemampuan dan impian peserta didiknya, serta selalu menguatkan semangat mereka untuk berhasil (Bustam et al., 2021). Dari hasil analisis data penelitian yang telah dilakukan, terungkap skor sikap kepribadian pendidik yang suka membangkitkan semangat peserta didiknya, hanya sebesar 19,67 atau $65,56 \%$ dari skor ideal 30 , dengan penilaian angka 3 , artinya pendidik kurang suka membangkitkan semangat peserta didik. Skor ini belum mencapai skor ideal yang 2114 | Jurnal Obsesi : Jurnal Pendidikan Anak Usia Dini, 6(3), 2022 
diharapkan, padahal setiap pendidik, diharapkan menjadi pembakar semangat, dan motivator sejati bagi peserta didiknya dalam kegiatan pembelajaran, dan bukan hanya mengajarkan materi pembelajaran saja. Perlu mendorong kemampuan berpikir kreatif peserta didiknya, dan menghindari sifat-sifat yang suka mematahkan semangat, sifat pesimistik, sikap membentak-bentak, meremehkan mereka, dan lain sejenisnya, sebab sifat negatif ini, menjadi wabah yang akan menghancurkan semangat belajar. Tetapi upaya memicu dan memacu peserta didik untuk belajar dengan motivasi yang tinggi dan semangat yang besar, sangat penting dalam kegiatan pembelajaran.

Salah satu hal yang perlu dimiliki oleh pendidik dalam kegiatan pembelajaran, adalah sikap kepribadian yang suka mendengar peserta didik, karena salah satu kebutuhan dasar peserta didik, adalah berbicara dan didengar. Mendengar dimaksud disini, adalah menghargai setiap pendapat peserta didik, mendengar keluhan, dan meresponi dengan penuh empati apa yang disampaikan oleh mereka (Erlangga, 2017). Dari hasil analisis data yang telah dilakukan, diperoleh skor tentang sikap kepribadian pendidik yang suka mendengar peserta didik, sebesar 19,25 atau $64,17 \%$ dari skor ideal 30 dengan penilaian angka 3 , artinya pendidik kurang suka mendengar peresrta didik dalam kegiatan pembelajaran. Skor ini belum mencapai skor ideal, dan perlu meningkatkan pribadi yang suka senyum kepada peserta didik. Dari hasil wawancara yang dilakukan kepada beberapa siswa terungkap bahwa ada siswa yang tidak berani berbicara kepada guru dalam kelas karena takut. Sudah biasa dan lumrah jika dalam kegiatan pembelajaran orang yang paling banyak berbicara adalah guru, dan sangat sedikit kesempatan untuk mendengarkan peserta didik. Padahal banyak yang perlu dibicarakan oleh peserta didik, dan sangat perlu untuk didengar oleh pendidik. Jika pendidik bersedia, suka mendengar, dan memberi kesempatan kepada peserta didik untuk berbicara dan didengar, berarti pendidik sedang memberikan hal yang positif, yaitu membuat mereka lebih aktif dan semakin termotivasi, menyukai guru dan pembelajaran yang diselenggarakannya. Sebaliknya jika pendidik tidak memberi kesempatan kepada peserta didik untuk berbicara dan didengar, dan lebih suka memotong pembicaraan, maka mereka akan menjadi jemu dan tidak menyenangi pendidik dan pembelajaran yang diselenggarakannya. Akibatnya, hasil pembelajaran yang diharapkan tidak tercapai.

Sifat ramah, senyum yang tulus dan jujur dari seorang pendidik, merupakan salah satu daya yang sangat besar dampak kekuatannya dalam membangkitkan motivasi yang tinggi dan semangat yang besar dalam diri peserta didik untuk belajar. Wajah suka senyum penuh kemesraan dengan tidak dibuat-buat, tulus dan jujur kepada peserta didik, juga menimbulkan dampak dan pengaruh positif, yang sangat besar kekuatannya kepada peserta didiknya, dalam kegiatan pembelajaran (Ramawati et al., 2021). Dari senyuman seorang pendidik saja, akan terlihat oleh mereka, dan tahu apakah gurunya seorang yang ramah atau tidak. Pendidik yang ramah penuh kemesraan, penyayang, bersahabat, lemah lembut, menyenangkan, memiliki sifat humor, dan lain sejenisnya, pasti disukai mereka, dan pembelajaran yang diselenggarakan. Berdasarkan hasil analisis data penelitian yang telah dilakukan, tentang sikap kepribadian pendidik yang suka senyum kepada peserta didik, diperoleh skor sebesar 19,25 atau $64,17 \%$ dari skor ideal 30 dengan penilaian 3, artinya pendidik kurang suka senyum kepada peserta didik pada kegiatan pembelajaran. Skor ini belum mencapai skor ideal yang diharapkan, atau kurang memiliki kesukaan senyum kepada peserta didik. Temuan ini diperkuat dengan hasil wawancara kepada siswa yang mengungkap bahwa ada guru yang ditakuti karena mukanya muram dan suka marah-marah di kelas. Pada hal senyum merupakan salah satu bahasa tubuh yang sangat besar kekuatannya untuk membuat rasa senang, baik kepada orang lain, peserta didik, maupun diri sendiri. Maka pendidik perlu tampil di depan peserta didiknya dengan wajah yang senyum senantiasa terhadap peserta didiknya.

Pendidik yang berhati mulia, pasti menghindari kebiasaan men-SOK (Salahkan, Omelin, Kritik) peserta didiknya, melainkan memperlakukan mereka dengan ramah, lembut, 
menyayangi, baik hati, bersahabat, berkata santun, menghargai, mengasuhnya dengan baik, dan lain sejenisnya, sebab semua peserta didik tidak suka di SOK atau dibentak-bentak, direndahkan, sikap bullying dan lain sejenisnya (Amoo et al., 2021). Dari hasil analisis data penelitian yang telah dilakukan, terungkap skor kepribadian pendidik yang menghindari kebiasaan men-SOK peserta didik sebesar 29,88 atau 66,88\% dari skor ideal 45 dengan penilaian angka 3, artinya pendidik kurang suka menghindari kebiasaan menyalahkan mengomelin, dan mengkritik peserta didik. Dari hasil wawancara yang dilakukan kepada beberapa orang siswa, terungkap bahwa ada guru yang menuduh dan menyalahkan siswa yang sebenarnya bukan kesalahannhya. Pada hal sebagai seorang profesional, pendidik harus menghindari kebiasaan ini, dan perlu memiliki sifat-sifat seperti lembut, menyenangkan, suka memberi dan tidak banyak menuntut, luwes, hangat, dapat menerima orang lain, mengenal dirinya sendiri, tidak berpura-pura, menghargai orang lain, tidak mau menang sendiri, dan obyektif. Selain itu, dia juga berupaya mengerti peserta didik, mengadakan penyesuaian, membina serta memelihara sikap ramah tamah dan sopan santun, mengusahakan agar setiap peserta didik merasa nyaman (Madukwe et al., 2019), memberikan ketenangan, menciptakan suasana tentram, rasa percaya, dan selalu berada dalam kondisi yang baik, serta meninggalkan prasangka-prasangka yang negatif.

Orang yang mengalami kesulitan terbesar dalam hidupnya, dan yang paling menyulitkan orang lain, adalah yang tidak mempunyai perhatian pada orang lain. Begitu juga dapat dikatakan bahwa salah satu masalah terbesar dalam kegiatan pembelajaran, adalah karena kurangnya kepedulian dan perhatian pendidik kepada peserta didiknya. Perhatian yang tulus dan jujur dari seorang pendidik, membawa dampak positif yang sangat besar terhadap motivasi belajar peserta didik, sebab pendidik yang pemerhati, pasti disenangi oleh peserta didiknya, dan kegiatan pembelajaran yang diselenggarakannya (Lilleheie et al., 2021). Dari hasil analisis data penelitian yang telah dilakukan diperoleh skor sikap kepribadian pendidik yang suka memberi perhatian yang tulus dan jujur kepada peserta didik, sebesar 19,58 atau $65,28 \%$ dari skor ideal 30 . Skor ini belum mencapai skor yang diharapkan, artinya pendidik kurang memberi perhatian yang tulus kepada peserta didiknya. Temuan ini diperkuat dengan hasil wawancara kepada beberapa siswa yang mengatakan bahwa ada guru yang sangat disukai karena guru tersebut ramah kepada mereka, dan begitu juga ada guru yang tidak disenangi bahkan ditakuti karena suka marah-marah. Sikap kepribadian yang pemerhati perlu dikembangkan oleh guru dalam dirinya.

Salah satu upaya membangkitkan motivasi belajar peserta didik, adalah membuat mereka menjadi orang penting dalam kegiatan pembelajaran. Upaya ini merupakan usaha untuk memberdayakan dan menghebatkan mereka untuk melakukan kegiatan belajar yang tinggi. Lemahnya semangat belajar, sering kali diakibatkan oleh sikap pendidik yang tidak mau dan pelit memenuhi rasa haus peserta didik menjadi orang penting (Kusumaningrum et al., 2019). Dari hasil analisis data penelitian yang telah dilakukan, diperoleh skor sikap kepribadian pendidik yang suka membuat peserta didik menjadi orang penting dalam pembelajaran sebesar 19,82 atau 66,06 dari skor ideal 30 dengan penilaian angka 3. Skor ini belum mencapai skor ideal yang diharapkan, artinya pendidik kurang suka membuat peserta didik menjadi orang penting dalam kegiatan pembelajaran. Padahal inilah salah satu upaya pendidik, untuk menciptakan motivasi yang tinggi dan semangat yang besar, dalam diri peserta didik untuk melakukan kegiatan belajar.

Menyebut nama peserta didik dengan benar dan tepat, berarti membangkitkan semangat untuk lebih giat belajar, dan ini sangat memberi pengaruh secara positif, bagi orang yang disebut namanya, yang membuatnya merasa diperlakukan secara istimewa. Rasa bangkit untuk lebih giat, muncul dalam diri individu, ketika namanya disebut, pendengarannya langsung meresponinya, karena nama adalah bunyi yang paling harum dan merdu bagi pemiliknya (Musofa et al., 2019). Dari hasil analisis data penelitian yang telah dilakukan, diperoleh skor sikap kepribadian pendidik yang suka menyebut nama peserta 
didik dengan benar dan tepat, sebesar 19,52 atau 65,06\% dari skor ideal 30 dengan penilaian angka 3. Skor ini belum mencapai skor ideal yang diharapkan, artinya pendidik kurang suka menyebut nama peserta didik dengan benar dan tepat dalam kegiatan pembelajaran. Dari hasil wawancara yang dilakukan kepada beberapa siswa, menyampaikan bahwa ada guru mereka yang sering menyebut siswa dengan kata-kata yang tidak baik, dan guru tersebut kurang disenangi. Pada hal kegiatan pembelajaran yang diselenggarakan pendidik, membutuhkan komunikasi dan interaksi yang efektif, harmonis, dan akrab serta salah satu upaya yang dilakukan, adalah menyebut nama peserta didik dengan benar dan tepat.

Kepedulian pendidik untuk menemukan dan membicarakan hal-hal menarik yang disukai oleh peserta didik, misalnya kesuksesan, masalah belajar, cita-cita, karir dan masa depan, hal-hal yang berkaitan dengan hidup sehari-hari, dan berbagai hal menarik lainnya dengan mangaitkannya pada pembelajaran, sangatlah penting dan dibutuhkan. Kurangnya perhatian dan tanggapan peserta didik, terhadap apa yang dibicarakan pendidik dalam kegiatan pembelajaran, adalah terlalu banyak hal tidak terkait dengan apa yang menarik dan diminati peserta didik (Laksana, 2019). Jika yang dibicarakan menarik dan disukai, maka mereka menyenangi pendidik dan pembelajaran yang diselenggarakan. Dari hasil analisis data penelitian yang telah dilakukan tentang kepribadian pendidik yang suka membicarakan hal-hal menarik dan disukai, diperoleh skor sebesar 19,32 atau 64,39\% dari skor ideal 30 dengan penilaian angka 3. Skor ini belum mencapai skor ideal yang diharapkan, artinya pendidik kurang suka membicarakan hal-hal menarik yang disukai dan diminati peserta didik dalam kegiatan pembelajaran. Padahal ini perlu dilakukan, agar kegiatan pembelajaran diikuti oleh peserta didik dengan fokus dan penuh antusias.

\section{SIMPULAN}

Sikap kepribadian guru PAUD, memiliki dampak besar terhadap motivasi belajar peserta didik. Sikap kepribadian guru pada kategori kurang, berdampak besar terhadap motivasi belajar peserta didik, baik secara positif maupun negatif. Sikap kepribadian guru PAUD yang menarik dan disukai oleh peserta didik seharusnya lebih ditingkatkan dan dikembangkan agar motivasi belajar anak didik dapat lebih meningkat.

\section{UCAPAN TERIMAKASIH}

Peneliti mengucapkan syukur kepada Tuhan Yang Maha Kuasa atas Rahmat-Nya, sehingga penelitian ini dapat diselesaikan dengan baik. Begitu juga diucapkan terima kasih kepada guru-guru PAUD di kota Gunungsitoli sekitarnya, yang telah bersedia menjadi responden penelitian ini. Juga kepada tim redaksi Jurnal Obsesi Pendidikan Usia Dini, yang telah bersedia menerima dan menerbitkan artikel hasil penelitian ini, serta pihka-pihak lain yang telah mendukung.

\section{DAFTAR PUSTAKA}

Abdullah, M. (2015). Metodologi Penelitian Kuantitatif. Aswaja Pressindo Yogyakarta.

Ahsani, E. luthfi F., \& Azizah, N. R. (2021). Implementasi Literasi Bud8. https://doi.org/10.23918/ijsses.v3i3p155

Amaruddin, H., Atmaja, H. T., \& Khafid, M. (2020).aya Dan Kewargaan Untuk Mengembangkan Keterampilan Sosial Siswa Madrasah Ibtidaiyah Di Tengah Pandemi. Jurnal Pendidikan Kewarganegaraan, 11(01), 7. https://doi.org/10.20527/kewarganegaraan.v11i01.10317

Altun, M. (2017). The Role of Passion in Effective Teaching and Learning. International Journal of Social Sciences \& Educational Studies, 3(3), 155-15. https://doi.org/10.23918/ijsses.v3i3p155 
Peran Keluarga Dan Media Sosial Dalam Pembentukan Karakter Santun Siswa Di Sekolah $\begin{array}{llll}\text { Dasar. Jurnal } \quad \text { Pendidikan } & \text { Karakter, }\end{array}$ https:// doi.org/10.21831/jpk.v10i1.30588

Amijaya, L. S., Ramdani, A., \& Merta, I. W. (2018). Pengaruh Model Pembelajaran Inkuiri Terbimbing Terhadap Hasil Belajar Dan Kemampuan Berpikir Kritis Peserta Didik. Jurnal Pijar Mipa, 13(2), 94. https:// doi.org/10.29303/jpm.v13i2.468

Amoo, S. A., Menlah, A., Garti, I., \& Appiah, E. O. (2021). Bullying in the clinical setting: Lived experiences of nursing students in the Central Region of Ghana. PLoS ONE, 16(9 September), 1-16. https://doi.org/10.1371/journal.pone.0257620

Ananda, R. (2017). The Effect of Learning Strategies and Learning Independence on Learning Outcomes in Learning Evaluation Subject. International Journal on Language, Research and Education Studies, 1(2), 340-350. https://doi.org/10.30575/2017/IJLRES2019091201.

Anwar, K., Asari, S., Husniah, R., \& Asmara, C. H. (2020). Students' Perceptions of Collaborative Team Teaching and Student Achievement Motivation. International Journal of Instruction, 14(1), 325-344. https:/ / doi.org/10.29333/iji.2021.14119a

Apriliani, E. I. (2019). Kesantunan Bahasa Anak Di Paud Mekar Sari Gondoriyo Kecamatan Jambu. Indonesian Journal of Early Childhood: Jurnal Dunia Anak Usia Dini, 1(2), 62. https:// doi.org/10.35473/ijec.v1i2.358

Aryani, R., \& Fauziah, P. Y. (2020). Analisis Pola Asuh Orangtua dalam Upaya Menangani Kesulitan Membaca pada Anak Disleksia. Jurnal Obsesi : Jurnal Pendidikan Anak Usia Dini, 5(2), 1128-1137. https://doi.org/10.31004/obsesi.v5i2.645

Ashsiddiqi, M. H. (2012). Kompetensi Sosial Guru Dalam Pembelajaran Dan Pengembangannya. Ta'dib:Journal of Islamic Education (Jurnal Pendidikan Islam), 17(01), 61-71. https:// doi.org/10.19109/tjie.v17i01.25.

Astuti, A. D., Hasan, S., \& Sodikin, A. (2021). Kompetensi Kepribadian Guru PAI dalam Membentuk Karakter Siswa MA. 8(1), 13-18.

Azis, A. (2017). Humanisme Dalam Pendidikan Islam: Konsepsi Pendidikan Ramah Anak. Jurnal Pendidikan Agama Islam (Journal of Islamic Education Studies), 5(1), 94. https:// doi.org/10.15642/jpai.2017.5.1.94-115

Baharun, H., \& Ummah, R. (2018). Strengthening Students' Character in Akhlaq Subject Through Problem Based Learning Model. Tadris: Jurnal Keguruan Dan Ilmu Tarbiyah, 3(1), 21. https:// doi.org/10.24042/tadris.v3i1.2205

Barseli, M., \& Ifdil, I. (2017). Konsep Stres Akademik Siswa. Jurnal Konseling Dan Pendidikan, 5(3), 143. https:// doi.org/10.29210/119800

Bas, S., \& Tabancali, E. (2020). Correlations between teachers' personality, psychological safety perception and teacher voice. Eurasian Journal of Educational Research, 2020(85), 185204. https://doi.org/10.14689/ejer.2020.85.9

Basalamah, M. S. A., \& As'ad, A. (2021). The Role of Work Motivation and Work Environment in Improving Job Satisfaction. Golden Ratio of Human Resource Management, 1(2), 94103. https://doi.org/10.52970/grhrm.v1i2.54

Bøsterud, C. E. (2021). Women in the Bible: What can they teach us about gender equality? In Die Skriflig / In Luce Verbi, 55(1), 1-9. https://doi.org/10.4102/ids.v55i1.2754

Boström, L., \& Bostedt, G. (2020). What about study motivation? Students' and teachers' perspectives on what affects study motivation. International Journal of Learning, $\begin{array}{llll}\text { Teaching and } \quad \text { Educational } & \text { 19(8), 59. }\end{array}$ https:// doi.org/10.26803/ijlter.19.8.3

Brown, N. (2004). What makes a good educator? The relevance of meta programmes. Assessment and Evaluation in Higher Education, 29(5), 515-533. https:// doi.org/10.1080/0260293042000197618 
Buttner, S., Pijl, S. J., Bijstra, J., \& Van Den Bosch, E. (2016). Personality traits of expert teachers of students with EBD: Clarifying a teacher's X-factor. International Journal of Inclusive Education, 20(6), 569-587. https:// doi.org/10.1080/13603116.2015.1100222

Cahyani, A., Listiana, I. D., \& Larasati, S. P. D. (2020). Motivasi Belajar Siswa SMA pada Pembelajaran Daring di Masa Pandemi Covid-19. IQ (Ilmu Al-Qur'an): Jurnal Pendidikan Islam, 3(01), 123-140. https:// doi.org/10.37542/iq.v3i01.57

Cheng, H.-F., \& Dörnyei, Z. (2007). The Use of Motivational Strategies in Language Instruction: The Case of EFL Teaching in Taiwan. Innovation in Language Learning and Teaching, 1(1), 153-174. https://doi.org/10.2167/illt048.0

Dang, T. B. D., Le, V. L., \& Ha, T. V. (2021). Factors Affecting Motivation of English-Majored Students Towards Learning English At a University in the Mekong Delta, Vietnam. European Journal of English Language Teaching, 6(6), 95-115. https://doi.org/10.46827/ejel.v6i6.3952

Darong, H. C., Kadarisman, A. E., Basthomi, Y., Suryati, N., Hidayati, M., \& Nima, E. M. (2020). What aspects of questions do teachers give attention To? International Journal of Innovation, Creativity and Change, 10(11), 191-208.

Djuwita, P. (2017). Pembinaan Etika Sopan Santun Peserta Didik Kelas V Melalui Pembelajaran Pendidikan Kewarganegaraan Di Sekolah Dasar Nomor 45 Kota Bengkulu. Jurnal PGSD, 10(1), 27-36. https:/ / doi.org/10.33369/pgsd.10.1.27-36

Dost, I. N., Bohloulzadeh, G., \& Hafshejani, N. K. (2017). The Impact of Teachers' Personality on Senior High School EFL Learners' General English Achievement. International Journal of English Literature and Social Sciences, 2(3), 77-93. https://doi.org/10.24001/ijels.2.3.9

Erlangga, E. (2017). Bimbingan Kelompok Meningkatkan Keterampilan Berkomunikasi Siswa. $\begin{array}{llll}\text { Psympathic: Jurnal Ilmiah } & \text { Psikologi, }\end{array}$ https://doi.org/10.15575/psy.v4i1.1332

Fadilah, N., Setyosari, P., \& Susilaningsih, S. (2021). Motivasi Belajar Mahasiswa Teknologi Pendidikan dalam Pembelajaran Online. JKTP: Jurnal Kajian Teknologi Pendidikan, 4(1), 90-97. https://doi.org/10.17977/um038v4i12021p090

Farista, R., \& M, I. A. (2018). Pengembangan Video Pembelajaran. Universitas Muhammadiyah Sidoarjo, 53(9), 1689-1699. https:/ / doi.org/10.17977/um038v3i32020p303.

Fitria, N., \& Sakmal, J. (2019). Pengaruh Metode Joyfull Learning Terhadap Hasil Belajar Ilmu Pengetahuan Alam Peserta Didik Kelas Iv Sekolah Dasar. Dinamika IPA Sekolah Dasar, 1(1), 1-11. https://journal.pgsdfipunj.com/index.php/ipa/article/view/133.

Fitriana, S. (2019). Peran Kepribadian Guru Dalam Proses Belajar Mengajar (Analisis KritisKonstruktif ata Pemikiran Zakiah Daradjat). Muslim Heritage: Jurnal Dialog Islam Dengan Realitas, 4(2), 281-300. https:// doi.org/10.21154/muslimheritage.v4i2.1798

Gani, E. (2019). Kesantunan Berbahasa Indonesia Dalam Tindak Tutur Melarang Dan Mengkritik Pada Tujuh Etni. Lingua, 15(2), 195-205.

Genç, E., \& Arslan, G. (2021). Optimism and dispositional hope to promote college students' subjective well-being in the context of the COVID-19 pandemic. Journal of Positive School Psychology, 5(2), 87-96. https://doi.org/10.47602/jpsp.v5i2.255

Ghofar, A. (2013). Penanaman Disiplin Pada Anak Usia Dini. Al-Misbah (Jurnal Islamic Studies), 1(1), 16-35. https:/ / doi.org/10.26555/almisbah.v1i1.83

Gilmore, L., Campbell, J., \& Cuskelly, M. (2003). Developmental Expectations, Personality Stereotypes, and Attitudes Towards Inclusive Education: Community and Teacher Views of Down Syndrome. International Journal of Disability, Development and Education, 50(1), 65-76. https://doi.org/10.1080/1034912032000053340

Ginja, T. G., \& Chen, X. (2020). Teacher educators' perspectives and experiences towards differentiated instruction. International Journal of Instruction, 13(4), 781-798. https://doi.org/10.29333/iji.2020.13448a 
Göncz, L. (2017). Teacher personality: a review of psychological research and guidelines for a more comprehensive theory in educational psychology. Open Review of Educational Research, 4(1), 75-95. https:/ / doi.org/10.1080/23265507.2017.1339572

Goodboy, A. K., Carton, S. T., Goldman, Z. W., Gozanski, T. A., Tyler, W. J. C., \& Johnson, N. R. (2014). Discouraging Instructional Dissent and Facilitating Students' Learning Experiences Through Instructor Self-Disclosure. Southern Communication Journal, 79(2), 114-129. https:// doi.org/10.1080/1041794X.2013.865256

Hafid, R., \& Asikin, A. (2020). model kooperatif; E-learning; peserta didik. 1, 81-90.

Hanna, -, Tjahjo Suprajogo, -, Muhsin Kalida, -, Heriyanti, -, Adiyati, -, \& Fathu Roshonah, -. (2020). Anticipation of Corruption through Literation Based Honest Behaviour Learning in Early Childhood Education. International Journal of Psychosocial Rehabilitation, 24(08), 1307-1319. https:// doi.org/10.37200/IJPR/V24I8/PR280145.

Hariyadi, A., \& Darmuki, A. (2019). Prestasi Dan Motivasi Belajar Dengan Konsep Diri. Prosiding Seminar Nasional, 0291, 280-286.

Hidayati, A. (2018). Peningkatan Keterampilan Berbicara Melalui Pendekatan Komunikatif Kelas V Sd Padurenan Ii Di Bekasi Tahun Pelajaran 2016/2017. Jurnal Ilmiah Pendidikan Dasar, 5(2), 83. https:// doi.org/10.30659/pendas.5.2.83-95

Huda, M. (2017). Kompetensi kepribadian guru dan motivasi belajar siswa ( Studi Korelasi $\begin{array}{llll}\text { pada Mata Pelajaran }) . & \text { 11(2), 237-266. }\end{array}$ https:// doi.org/10.21043/jupe.v11i2.3170

Idris, Z., Johari, K. S. K., \& Bakar, A. Y. A. (2018). Meta-Synthesis Study: Positive Effects on Positive Personality of Teachers in Teaching Profession. International Journal of Academic Research in Business and Social Sciences, 8(1). https://doi.org/10.6007/IJARBSS/v8-i1/3844

Inggriani, S., Sabandi, A., Pendidikan, A., \& Padang, U. N. (2021). Komitmen Guru Dalam Melaksanakan Tugas di Sekolah Menengah Kejuruan ( SMK) Negeri Se-Kota Solok. 5, 4593-4597.

Kahar, M. S. (2018). Motivation Analysis Learning in The Implementation of Physics Practicum. Formatif: Jurnal Ilmiah Pendidikan MIPA, 8(1), 1-6. https:// doi.org/10.30998/formatif.v8i1.2304

Kamandoko, G. (2009). 100 Kisah Jenaka untuk Anak Muslim. Mizan.

Kaso, N., Mariani, M., Ilham, D., Firman, F., Aswar, N., \& Iksan, M. (2021). The Principal's Leadership: How to Improve the Quality of Teaching and Learning Process in State Junior High School of Luwu. Jurnal Ad'ministrare, 8(1), 49. https:// doi.org/10.26858/ja.v8i1.19126

Khaidir, M. A., Kosilah, S. S., Kistian, A., Dafiq, N., Psi, S., Miswar Saputra, M. P., ... \& S Pd I, M. S. I. (2021). Pendidikan Akhlak Anak Usia Dini. Yayasan Penerbit Muhammad Zaini.

Khairani, I., \& Safitri, R. (2018). Penerapan Metode Pembelajaran Problem Solving Untuk Meningkatkan Hasil Belajar Peserta Didik Pada Materi Usaha Dan Energi Di Man Rukoh Banda Aceh. Jurnal Pendidikan Sains Indonesia, 5(2), 32-41. https:// doi.org/10.24815/jpsi.v5i2.9814

Koerstoer. (1985). Bimbingan dan Penyuluhan di Sekolah (Jilid I) (III). Erlangga Jakarta.

Komarudin, K., \& Subekti, B. H. (2021). Tingkat Kepuasan Peserta Didik Terhadap Pembelajaran Pjok Daring. Jambura Health and Sport Journal, 3(1), 16-23. https:// doi.org/10.37311/jhsj.v3i1.9847

Krys, K., -Melanie Vauclair, C., Capaldi, C. A., Lun, V. M. C., Bond, M. H., DomínguezEspinosa, A., Torres, C., Lipp, O. V., Manickam, L. S. S., Xing, C., Antalíková, R., Pavlopoulos, V., Teyssier, J., Hur, T., Hansen, K., Szarota, P., Ahmed, R. A., Burtceva, E., Chkhaidze, A., ... Yu, A. A. (2016). Be Careful Where You Smile: Culture Shapes 
Judgments of Intelligence and Honesty of Smiling Individuals. Journal of Nonverbal Behavior, 40(2), 101-116. https:// doi.org/10.1007/s10919-015-0226-4

Kumar, M. (2019). International Journal of English Literature and Social Sciences (IJELS). https://doi.org/10.22161/ijels

Kusuma Wardani, D. M., \& Brantasari, M.-. (2019). Peningkatan Nilai-Nilai Agama Dan Moral Pada Anak Kelompok B Beragama Hindu Melalui Metode Bercerita Di Tk Tunas Bangsa Tenggarong Seberang Tahun Pelajaran 2018/2019. Jurnal Warna : Pendidikan Dan Pembelajaran Anak Usia Dini, 4(2), 97-109. https:/ / doi.org/10.24903/jw.v4i2.374

Kusumaningrum, D. E., Sumarsono, R. B., \& Gunawan, I. (2019). Professional ethics and teacher teaching performance: Measurement of teacher empowerment with a soft system methodology approach. International Journal of Innovation, Creativity and Change, 5(4), 611-624.

Laksana, D. N. L., \& Seso, M. A. (2019). Desain Pembelajaran Konstekstual Spirit Meda Mazi Di Sd Kelas Rendah. Journal of Education Technology, 2(1), 1. https://doi.org/10.23887/jet.v2i1.13799

Lase, F. (2016). Kompetensi Kepribadian Guru Profesional. Jurnal PPKn Dan Hukum, 11(1), 36-66. https:// ejournal.unri.ac.id/index.php/JPB/article.

Le, T. T. M. (2021). A Case Study of Students' Views on Effective Online Learning. AsiaCALL Online Journal, 12(5), 24-33.

Lesser, L. M., Pearl, D. K., \& Weber, J. J. (2016). Assessing fun items' effectiveness in increasing learning of college introductory statistics students: Results of a randomized experiment. Journal of Statistics Education, 24(2), 54-62. https://doi.org/10.1080/10691898.2016.1190190

Lilleheie, I., Debesay, J., Bye, A., \& Bergland, A. (2021). The tension between carrying a burden and feeling like a burden: a qualitative study of informal caregivers' and care recipients' experiences after patient discharge from hospital. International Journal of Qualitative Studies on Health and Well-Being, 16(1). https://doi.org/10.1080/17482631.2020.1855751

Lohbeck, A., \& Frenzel, A. C. (2021). Latent motivation profiles for choosing teaching as a career: How are they linked to self-concept concerning teaching subjects and emotions during teacher education training? British Journal of Educational Psychology, 1-22. https://doi.org/10.1111/bjep.12437

Lukman, Marsigit, Istiyono, E., Kartowagiran, B., Retnawati, H., Kistoro, H. C. A., \& Putranta, H. (2021). Effective teachers' personality in strengthening character education. International Journal of Evaluation and Research in Education, 10(2), 512-521. https:// doi.org/10.11591/ijere.v10i2.21629

Lumban Gaol, N. T., \& Nababan, A. (2019). Kepemimpinan Guru Pendidikan Agama Kristen. Kelola: Jurnal Manajemen Pendidikan, 69-96. https://doi.org/10.24246/j.jk.2019.v6.i1.p89-96

Luo, N., Zhang, Y., \& Zhang, M. (2019). Retaining learners by establishing harmonious relationships in e-learning environment. Interactive Learning Environments, 27(1), 118-131. https:// doi.org/10.1080/10494820.2018.1506811

Madukwe, P., Onwuka, U., \& Nyejirime, W. Y. (2019). Teachers ' Attitude as a Correlate of Students ' Academic Performance. International Journal of Research and Innovation in Social Science, 3(1), 205-209.

Mahmudah, M. (2018). Pengelolaan Kelas: Upaya Mengukur Keberhasilan Proses Pembelajaran. Jurnal Kependidikan, 6(1), 53-70. https://doi.org/10.24090/jk.v6i1.1696

McDevitt, S. E. (2021). Teaching immigrant children: learning from the experiences of immigrant early childhood teachers. Journal of Early Childhood Teacher Education, 42, 123-142. https://doi.org/10.1080/10901027.2020.1818650 
Melrose, S., \& Bergeron, K. (2021). International Review of Research in Open and Distributed Learning Online Graduate Study of Health Care Learners ' Perceptions of Instructional Immediacy Online Graduate Study of Health Care Learners ' Perceptions of Instructional Immediacy.

Moh Ghoizi Eriyanto, M.V. Roesminingsih, Soedjarwo, \& Ivan Kusuma Soeherman. (2021). The Effect of Learning Motivation on Learning Independence and Learning Outcomes of Students in the Package C Equivalence Program. IJORER: International Journal of Recent Educational Research, 2(4), 455-467. https://doi.org/10.46245/ijorer.v2i4.122

Mohammad, T., \& Hazarika, Z. (2016). Difficulties of Learning EFL in KSA: Writing Skills in Context. International Journal of English Linguistics, 6(3), 105. https://doi.org/10.5539/ijel.v6n3p105

Mudiyah, \& Watini, S. (2021). Peningkatan Kemampuan Berbicara Anak melalui Media Boneka Jari pada Anak Usia 4 - 5 Tahun di TK Adifa Karang Mulya Kota Tangerang. Jurnal Pendidikan Tambusai, 5(2), 4258-4265. https://www.jptam.org/index.php/jptam/article/view/1545.

Muhyatun, M. (2019). Upaya Preventif Perilaku Menyontek Siswa Melalui Layanan Dukungan Sistem. BELAJEA: Jurnal Pendidikan Islam, 4(2). https:// doi.org/10.29240/belajea.v4i2.891

Muis, T. (2017). Tindakan Kekerasan Guru Terhadap Siswa dalam Interaksi Belajar Mengajar (Studi Kasus di SMAN Surabaya). Jurnal Pendidikan (Teori Dan Praktik), 2(1), 86. https://doi.org/10.26740/jp.v2n1.p86-90

Mulang, H. (2021). The Effect of Competences, Work Motivation, Learning Environment on Human Resource Performance. Golden Ratio of Human Resource Management, 1(2), 84-93. https://doi.org/10.52970/grhrm.v1i2.52

Muna, N. (2020). Strategi Guru BK dalam Mengatasi Burnout Study Siswa SMKN 1 Widasari. Islamic Counseling: Jurnal Bimbingan Konseling Islam, 4(1), 81. https:// doi.org/10.29240/jbk.v4i1.1444

Munro EA, D. (1993). Penyuluh, Suatu Pendekatan Berdasarkan Keterampilan (Terjemahan Erman Amti). Dikti Depdikbud.

Murti, S. dan heryanto. (2020). Jurnal Ilmiah Wahana Pendidikan. Jurnal Ilmiah Wahana Pendidikan Https://Jurnal.Unibrah.Ac.Id/Index.Php/JIWP, 6(3), 295-307. https:// doi.org/10.5281/zenodo.3737983.

Musofa, M., Casmini, C., \& Sutrisno, S. (2019). Pencarian Makna Hidup Siswa dari Keluarga Miskin di Kabupaten Wonosobo. Psympathic: Jurnal Ilmiah Psikologi, 6(1), 85-98. https://doi.org/10.15575/psy.v6i1.4076

Mustopo, M. (1987). Ilmu Budaya Dasar. Usaha Nasional Surabaya.

Nasution, I. (2019). Kompetensi Kepribadian Guru PAUD Dan Upaya Pengembangannya. Perdana Publishing.

Noreen, S., Ali, A., \& Munawar, U. (2019). The Impact of Teachers' Personality on Students' Academic Achievement in Pakistan. Global Regional Review, IV(III), 92-102. https:// doi.org/10.31703/grr.2019(IV-III).11

Norsidah Ahmad, Mohd Khairy Kamarudin, \& Kamarul Azmi Jasmi. (2017). The Concept of Teachers ' Personality in Shaping Students ' Characters The Concept of Teachers ' Personality in Shaping Students ' Characters. Research Journal of Education, 3(11), 157163.

Novitasari, D., Asbari, M., Purwanto, A., Fahmalatif, F., Sudargini, Y., Hidayati, L., \& Wiratama, J. (2021). The Influence of Social Support Factors on Performance: A Case Study of Elementary School Teachers. International Journal of Social and Management Studies (IJOSMAS), 01(01),

41-52. https:// doi.org/https:// doi.org/10.5555/ijosmas.v2i1.6. 
Nugroho, L. A., Sayekti, I. C., \& Eryani, R. (2021). Peranan Reward Untuk Meningkatkan Motivasi Belajar Tema 9 Kayanya Negeriku Di Kelas IV SD Negeri Pungsari 1 Kecamatan Plupuh. Journal of Education Research, 3(4), 30-36.

Oktawirawan, D. H. (2020). Faktor Pemicu Kecemasan Siswa dalam Melakukan Pembelajaran Daring di Masa Pandemi Covid-19. Jurnal Ilmiah Universitas Batanghari Jambi, 20(2), 541. https:// doi.org/10.33087/jiubj.v20i2.932

Oktiani, I. (2017). Kreativitas Guru dalam Meningkatkan Motivasi Belajar Peserta Didik. Jurnal Kependidikan, 5(2), 216-232. https:// doi.org/10.24090/jk.v5i2.1939

Oktradiksa, A. (2012). Pengembangan Kualitas Kepribadian Guru. Nadwa: Jurnal Pendidikan Islam, 6(2), 231-248. https:// doi.org/10.21580/nw.2012.6.2.590

Perryman, J., \& Calvert, G. (2020). What Motivates People To Teach, and Why Do They Leave? Accountability, Performativity and Teacher Retention. British Journal of Educational Studies, 68(1), 3-23. https://doi.org/10.1080/00071005.2019.1589417

Pertemuan, U., \& Organisasi, D. (2021). Dawatuna : Journal of Communication and Islamic Broadcasting Dawatuna : Journal of Communication and Islamic Broadcasting. 1, 109119. https:// doi.org/10.47467/dawatuna.v1i2.487

Portana, H. V., Fronda, J. G., Policarpio, D. G. T., Rigat, K. A. R. C., \& A. Llames, G. (2021). Effectiveness and Acceptability of Instructional Materials in the Enhancement of Students' Academic Achievement. International Journal of Advanced Engineering, Management and Science, 7(1), 12-15. https://doi.org/10.22161/ijaems.71.2

Pratiwi, W. A., Prasetyo, I., \& Shabrina, M. N. (2021). Faktor-Faktor yang Berpengaruh terhadap Kinerja Guru Taman Kanak-Kanak. Jurnal Obsesi : Jurnal Pendidikan Anak Usia Dini, 5(2), 1741-1753. https:// doi.org/10.31004/obsesi.v5i2.970

Prayitno. (2019). Panuduan Alat Ungkap Masalah Kegiatan Belajar (AUM PTSDL). Jurusan Bimbingan dan Konseling FIP UNP.

Purbalingga, T. P. A. S., Purwokerto, I., Purwokerto, I., \& Purbalingga, C. (2021). Jurnal asghar. $1,60-81$.

Rafiola, R. H., Setyosari, P., Radjah, C. L., \& Ramli, M. (2020). The effect of learning motivation, self-efficacy, and blended learning on students' achievement in the industrial revolution 4.0. International Journal of Emerging Technologies in Learning, 15(8), 7182. https://doi.org/10.3991/ijet.v15i08.12525

Rahardi, K. (2011). Humor Ada Teorinya: Bahasa dan Gaya Melawak. Pinus Book Publisher.

Rahman, M. H. (2017). Using Discovery Learning to Encourage Creative Thinking. International Journal of Social Sciences \& Educational Studies, 4(2). https://doi.or https://doi.org/10.23918/ijsses.v4i2sip98

Rai Utama, B. I. G. (2017). Pemasaran Pariwisata (EdisiI) (I). Andi Yogyakarta.

Ramawati, D. D., Syafitei, Y., \& Pratama, Y. A. J. (2021). Buletin literasi budaya sekolah. Pendidika, 3(Mutu Pendidikan), 4. https:/ / doi.org/10.23917/blbs.v3i.

Rasam, F., \& Sari, A. I. C. (2018). Peran Kreativitas Guru Dalam Penggunaan Media Belajar Dan Minat Belajar Dalam Meningkatkan Prestasi Belajar Peserta Didik Smk Di Jakarta Selatan. Research and Development Journal of Education, 5(1), 95. https://doi.org/10.30998/rdje.v5i1.3391

Robinson, M. D., \& Eid, M. (2017). The happy mind: Cognitive contributions to well-being. The Happy Mind: Cognitive Contributions to Well-Being, 1-480. https://doi.org/10.1007/978-3-319-58763-9

Rosid, M. (2021). Analisis Keterampilan Guru Dalam Komunikasi Dengan Peserta Didik Di SMA Negeri Tegaldlimo Banyuwangi. Jurnal Edukasi, 8(1), 23. https://doi.org/10.19184/jukasi.v8i1.24510

Rumayar, Elizabeth. (2011). Bagaimana Menciptakan Hubungan yang Baik dengan Orang Lain. Jurnal Ilmiah Unklab, 15(2), 78-88. 
Rumbewas, S. S., Laka, B. M., \& Meokbun, N. (2018). Peran Orang Tua Dalam Miningkatkan Motivasi Belajar Peserta Didik di Sd Negeri Saribi. Jurnal EduMatSains, 2(2), 201-212.

Sakliressy, M. T., Sunarno, W., \& Nurosyid, F. (2021). Profil Sikap Ilmiah Peserta Didik Dalam Pembelajaran Fisika di SMA YPPK Teruna Bakti Jayapura. Jurnal Penelitian Pembelajaran Fisika, 12(1), 66-71. https:// doi.org/10.26877/jp2f.v12i1.8025

Sandi, A. L., Amirudin, \& Sitika, A. J. (2021). The Role of Teacher's Teaching Style and Motivation in Improving Learning Outcomes of Islamic Religious Education at Sindangmulya 04 State Elementary School (SDN), Cibarusah. INFLUENCE: International Journal of Science Review, 3(1), 1-8. http://internationaljournal.net/index.php/influence/article/view/109. https:// doi.org/10.54783/influence.v3i1.109

Santoso, A. M., Amin, M., Sumitro, S. B., \& Lukiati, B. (2017). Learning Motivation of Students During the Implementation of Lecturing Based in Silico Approach. International Journal of Research and Review, 4(9), 6-9. http:/ / www.gkpublication.in/IJRR_Vol.2_Issue6_June2015/IJRR0066.pdf.

Sari, A. (2017). Implementasi Pendidikan Karakter Di Sekolah Melalui Kegiatan Pembiasaan Dan Keteladanan. Tarbawi: Jurnal Keilmuan Manajemen Pendidikan, 3(02), 249. https://doi.org/10.32678/tarbawi.v3i02.1952

Sari, A., \& Sumiati, A. (2016). Hubungan Antara Dukungan Sosial Dengan Efikasi Diri Pada Siswa Kelas X Akuntansi Di Smk Bina Pangudi Luhur Jakarta. Econosains Jurnal Online Ekonomi Dan Pendidikan, 14(2), 16-25. https://doi.org/10.21009/econosains.0142.02

Sejati, A. E., Kasmiati, S., \& Ikhsan, F. A. (2019). The relationship between learning process interactions and student's learning outcomes in environmental sustainability matter geography-social science education subject. IOP Conference Series: Earth and Environmental Science, 382(1). https:// doi.org/10.1088/1755-1315/382/1/012026

Septian, A., \& Komala, E. (2019). Kemampuan Koneksi Matematik Dan Motivasi Belajar Siswa Dengan Mengunakan Model Problem-Based Learning (Pbl) Berbantuan Geogebra Di Smp. Prisma, 8(1), 1. https:// doi.org/10.35194/ip.v8i1.438

Setiawan, H. (2017). Bagaimana Wujud Kesantunan Berbahasa Guru? Studi Kasus di SD Immersion Ponorogo. Gramatika STKIP PGRI Sumatera Barat, 3(2). https:// doi.org/10.22202/jg.2017.v3i2.2003

Sihaloho, G. T., Sitompul, H., \& Appulembang, O. D. (2020). Peran Guru Kristen Dalam Meningkatkan Keaktifan Siswa Pada Proses Pembelajaran Matematika Di Sekolah Kristen [the Role of Christian Teachers in Improving Active Learning in Mathematics in a Christian School]. JOHME: Journal of Holistic Mathematics Education, 3(2), 200. https:// doi.org/10.19166/johme.v3i2.1988

Simkhada, B., Vahdaninia, M., van Teijlingen, E., \& Blunt, H. (2021). Cultural issues on accessing mental health services in Nepali and Iranian migrants communities in the UK. International Journal of Mental Health Nursing, 000. https://doi.org/10.1111/inm.12913

Sogunro, O. A. (2014). Motivating Factors for Adult Learners in Higher Education. International Journal of Higher Education, 4(1), 22-37. https://doi.org/10.5430/ijhe.v4n1p22

Stark, K., \& Bettini, E. (2021). Teachers' perceptions of emotional display rules in schools: A systematic review. Teaching and Teacher Education, 104, 103388. https://doi.org/10.1016/j.tate.2021.103388

Sternberg, R. J., \& Grigorenko, E. L. (2007). Teaching for successful intelligence: To increase student learning and achievement. Corwin Press.

Sugiyono. (2015). Metode Penelitian Manajemen (Cetakan Ke). AlfaBeta Bandung. 
Sumiati, S., \& Triposa, R. (2021). Prinsip Guru Pendidikan Agama Kristen Memotivasi Belajar Peserta Didik dalam Perspektif Alkitab. Harati: Jurnal Pendidikan Kristen, 1(1), 69-84. https://doi.org/10.54170/harati.v1i1.31

Suplig, M. A. (2017). The Effect of Online Game Addiction of Class X High School Students on the Social Intelligence of Private Christian Schools in Makassar. Jurnal Jaffray, 15(2), 177. https:// doi.org/10.25278/ji71.v15i2.261

Supriyanto, A., Hartini, S., \& Sutoyo, A. (2019). Indicators of professional competencies in research of Guidance and Counseling Teachers. 9(1), 53-64. https://doi.org/10.25273/counsellia.v9i1.3927

Suyatno, Pambudi, D. I., Mardati, A., Wantini, Nuraini, E., \& Yoyo. (2019). The education values of Indonesian teachers: Origin, importance, and its impact on their teaching. International Journal of Instruction, 12(3), 633-650. https://doi.org/10.29333/iji.2019.12338a

Syahrani, A., Asfar, D. A., Perdana, I., \& Pattiasana, P. J. (2021). JURNAL KOMUNIKASI PROFESIONAL Mendengarkan dan berbicara untuk berkomunikasi : apa yang guru lakukan dan siswa pelajari dari penilaian kelas. 5(4), 335-344. https://doi.org/10.25139/jkp.v5i4.3908

Tamara, R. M. (2016). Peranan Lingkungan Sosial Terhadap Pembentukan Sikap Peduli Lingkungan Peserta Didik Di Sma Negeri Kabupaten Cianjur. Jurnal Geografi Gea, 16(1), 44. https://doi.org/10.17509/gea.v16i1.3467

Tasgin, A., \& Coskun, G. (2018). The relationship between academic motivations and university students' attitudes towards learning. International Journal of Instruction, 11(4), 935-950. https:// doi.org/10.12973/iji.2018.11459a

Triwardhani, I. J., Trigartanti, W., Rachmawati, I., \& Putra, R. P. (2020). Strategi Guru dalam membangun komunikasi dengan Orang Tua Siswa di Sekolah. Jurnal Kajian Komunikasi, 8(1), 99. https:// doi.org/10.24198/jkk.v8i1.23620

Troy Frensley, B., Stern, M. J., \& Powell, R. B. (2020). Does student enthusiasm equal learning? The mismatch between observed and self-reported student engagement and environmental literacy outcomes in a residential setting. Journal of Environmental Education, 51(6), 449-461. https:// doi.org/10.1080/00958964.2020.1727404

Tyas, E. H., \& Naibaho, L. (2021). Hots Learning Model Improves the Quality of Education. International Journal of Research -GRANTHAALAYAH, 9(1), 176-182. https://doi.org/10.29121/granthaalayah.v9.i1.2021.3100

Van Urk-Coster, E. (2021). Created in the Image of God: Both Human and Non-Human Animals? Theology and Science, $0(0), \quad 1-20$. https:// doi.org/10.1080/14746700.2021.1982248

Vega, A. De, Hapidin, H., \& Karnadi, K. (2019). Pengaruh Pola Asuh dan Kekerasan Verbal terhadap Kepercayaan Diri (Self-Confidence). Jurnal Obsesi : Jurnal Pendidikan Anak Usia Dini, 3(2), 433. https://doi.org/10.31004/obsesi.v3i2.227

Wahono, B., Lin, P. L., \& Chang, C. Y. (2020). Evidence of STEM enactment effectiveness in Asian student learning outcomes. International Journal of STEM Education, 7(1), 1-18. https://doi.org/10.1186/s40594-020-00236-1

Warsah, I., \& Uyun, M. (2019). Kepribadian Pendidik: Telaah Psikologi Islami. Psikis : Jurnal Psikologi Islami, 5(1), 62-73. https:// doi.org/10.19109/Psikis.v5i1.3157

Werdani, Y. D. W., \& Prasetya, A. W. (2021). Exploring Psychological Condition of Breast Cancer Survivor After Mastectomy and Chemotherapy. Jurnal Kesehatan Prima, 15(1), 13. https://doi.org/10.32807/jkp.v15i1.512

Wulandani, T. B. (2021). Peran Guru Dalam Peningkatan Kualitas Belajar Peserta Didik Pada Pembelajaran Daring Di Madrasah Ibtidaiyah. EDUCARE: Journal of Primary Education, 2(1), 75-86. https:// doi.org/10.35719/educare.v2i1.47 
Xu, S. Q., \& Cooper, P. (2020). Mainstream teachers' perceptions of individual differences among students in inclusive education settings of China. International Journal of Inclusive Education, 0(0), 1-19. https://doi.org/10.1080/13603116.2020.1735541

Yanti, R., Kubuwono, H., \& Ristianti, D. H. (2020). Sikap Siswa Terhadap Guru Dan Faktor Yang Mempengaruhinya. Journal of Education and Instruction, 3, 222-230.

$\mathrm{Yu}, \mathrm{Z}$. (2021). The effects of gender, educational level, and personality on online learning outcomes during the COVID-19 pandemic. International Journal of Educational Technology in Higher Education, 18(1). https:// doi.org/10.1186/s41239-021-00252-3

Ziyaeemehr, A., Kumar, V., \& Abdullah, M. (2011). Use and Non-use of Humor in Academic ESL Classrooms. English Language Teaching, 4(3), 111-119. https://doi.org/10.5539/elt.v4n3p111 